\title{
ADP-Ribosylation Factor 6
}

National Cancer Institute

\section{Source}

National Cancer Institute. ADP-Ribosylation Factor 6. NCI Thesaurus. Code C143145.

ADP-ribosylation factor $6(175 \mathrm{aa}, \sim 20 \mathrm{kDa})$ is encoded by the human ARF6 gene. This protein plays a role in protein localization and the remodeling of both lipid membranes and the cytoskeleton. 